\title{
Robert D. Tollison: A remembrance
}

\author{
Michael Munger ${ }^{1}$
}

Received: 27 December 2016/Accepted: 31 January 2017/Published online: 27 February 2017

(C) Springer Science+Business Media New York 2017

I met Bob in the early 1980s. He was called-unkindly, but not entirely inaccurately"Dollar Bob" Tollison, for his habit (as the story was told) of moving whenever the benefits from moving, net of moving costs, exceeded one full American dollar. His list of "full-time" appointments included Longwood College, Cornell, Texas A\&M (where he was promoted twice, and appointed chair, within just 5 years of finishing his Ph.D.), Miami, Virginia Tech, the Federal Trade Commission, Clemson 1.0, George Mason, Mississippi, and then Clemson 2.0.

The setting for our meeting was the Public Choice Society; I was a discussant for one of Bob's (coauthored, obviously) papers. As I talked, I noticed that Bob was becoming agitated, finally bursting out, "No! None of that's right! You're just wrong!" We talked a bit afterward, and just decided to agree to disagree. I assumed that we were enemies; we ended up being friends. Bob cared deeply about his work, and was interested in getting things right. But when it came to people he was incredibly warm-though he pretended that he was mean-and loyal, perhaps to a fault - though he wanted to be seen as rationally selfish. It is to Bob's warmth, and loyalty, that I owe much of whatever success I have had in academics.

\section{FTC and George Mason}

My first job out of grad school, in 1984, was at the U.S. Federal Trade Commission (FTC) in Washington, DC, USA. I just missed having Bob as a colleague, or rather boss, since he directed the Bureau of Economics, a job taken over by Dr. Wendy Gram by the time I arrived. But people still talked about him, not always fondly given his views and the goals of many professional bureaucrats.

Michael Munger

mcmunger@gmail.com

1 Duke University, Durham, NC, USA 
Later, in 1990, when I had moved from University of Texas to the University of North Carolina, I was able to visit George Mason, Bob's home from 1984 through 1998, whenever I drove up to work with my frequent co-author Kevin Grier. One of the key institutions of the Economics Department at that time was the noon pick-up basketball game. I was no better at basketball than I was at discussing academic papers, but Bob was more tolerant of error on the court. To his credit (and as pointed out by Peter Boettke 2016), Bob himself didn't make that many mistakes; in Pete's words, "He had an amazingly accurate three-point shot."

One of the impressive things about Bob's management style, when he was Director of the Center for Study of Public Choice (1984-1998), was his efficiency. He made fun of his own laziness (and almost everything else), but if you paid attention you noticed that things ran well. The programs of the Center all worked, the seminars were well attended and a sense of shared purpose was evident. You can say that that was because Buchanan, Tullock, Wagner, and the other luminaries of the Center all drove and supported those norms, and that's certainly true. But I have learned-as a long-time administrator myself-that if an organization runs well the person directing it is fostering those good norms and helping them function in ways that may not be obvious. Bob's restless energy was almost infinite, and he could have a conversation, watch television or do a crossword puzzle, and work on writing a (again, nearly always coauthored) paper, all at the same time.

Bob's loyalty to those on his team was legendary. He had a team mentality, and always wanted to share, as long as he was on the team, too. Bob was as proud of an assist as a score, though any time he was open he would put the ball up. But his loyalty extended to organizations, such as the books and journals he edited and the academic societies in which he participated.

For me, this loyalty provided one of the key "assists" in my academic life. In 1996, I was trying hard to get a job at Duke University. Like many universities that see themselves (perhaps rightly) as exclusive, Duke had questions about my academic prominence and potential. But at the 1996 Public Choice meetings in Houston, Texas, Bob announced that I would follow him as President of the Society.

To be fair, the constitution of the Public Choice Society was pretty simple: each outgoing president chooses his or her successor. The president is welcome to solicit advice, but does not need consent, from the membership of the Society or the Executive Board of former presidents, which serves as a kind of governing body. Bob felt that I deserved a chance to work on organizing the Society along more modern lines (his main goal was to have, for the first time, an on-line presence, with a web page, on-line paper submissions, and web-based registration for the meetings). He thought I could do that, and he felt that I had shown proper respect for the traditions of the "Virginia School" approach to Public Choice.

So, over the (in many ways justified; I was an Associate Professor!) objections from other members and deserving candidates, I was named president. At the reception that year, one angry member demanded, "How could someone like you get power in this organization?" (As far as I know, the 1996 meetings were the last time that worthy attended.) I'd like to think my presidency, and subsequent events, have vindicated Bob's choice. We developed a web site, and an on-line version of the program, and a process for registering through the web site.

But those later events, including my offer of a tenured position at Duke, all were partly a consequence of Bob's choice, and Bob's fierce loyalty. My career path would be completely different if it were not for Bob's intervention and trust, and I owe him a great deal for that. 


\section{Easy to like, easy to underestimate}

Bob was an easy fellow to like, though he could get angry, and his usual approach to cheering someone up seemed merciless, because he just made fun of you until you got so mad you forgot why you were upset in the first place. But Bob was also an easy person to underestimate. Being myself from the South, I knew that the "Ah'm just an ol' country boy, don't know much..." act meant that you should check for your wallet. But Bob's selfdeprecating manner and general ironic detachment from the game of academics could be misleading.

In fact, Bob was fiercely competitive locally, even as he was fiercely loyal on a larger scale. If you played golf with Bob and Anna, you were treated to 18 holes of abuse and mockery, with Bob trying to win every shot and every hole. That drive, and that work ethic, were very much in keeping with James Buchanan's approach to the "game" of academics, though Bob's demeanor could not have been more different.

That competitiveness and drive clearly bore fruit, perhaps to an extent that the casual observer might find surprising. The data make this clear:

1. Of nearly 50,000 economists listed on the ideas.repec.org website, Bob is listed as the 862 nd most prominent, putting him in the top $2 \%$ of all economists, all time, in any field.

2. Tollison's work had well over 10,000 citations in total, making him one of most prominent scholars in the history of public choice.

3. Two of Bob's relatively early journal publications, "Rent seeking: A survey" (1982) and "Public Choice and Legislation" (1988), were solo-authored, and appeared in hundreds of reference lists and graduate syllabi for two decades. But even those papers were attempts to advance the goals of the team, connecting the research of many people in the public choice movement to larger literatures.

\section{Final words}

The remarkable things about Robert Tollison actually were unremarkable. He was a team player, loyal to those who were part of his intellectual movement, and eager to dish out assists right and left. His work on the journal Public Choice helped keep it in a place of distinction in both political science and economics. Many of us, and myself more than most, owe Bob an eternal debt of gratitude.

\section{References}

Boettke, P. (2016). Robert Tollison-Economist, political economist and mentor to so any (1942-2016). http://www.coordinationproblem.org/2016/10/index.html.

Tollison, R. (1982). Rent seeking: A survey. Kyklos, 4, 575-602.

Tollison, R. (1988). Public choice and legislation. Virginia Law Review, 74, 339-371. 